\title{
New Rhizobial Bacteria of the Genus Sinorhizobium Fredii Entering Symbiosis with Soybean Plants
}

\author{
Bakhtiyor Umarov* \\ Department of Natural Sciences, Uzbek State University of World Languages Tashkent, Uzbekistan
}

\begin{abstract}
For the first time in the soils of the Tashkent region were isolated fast growing types of nodule bacteria of the genus Sinorhizobium fredii from the soybean plants. Were studied of symbiotic properties of isolated microorganisms in sterile conditions with soybean plants. In the genome of the isolated strains was found from 2 to 3 mega plasmids related only to these types of bacteria.
\end{abstract}

KEYWORDS: Sinorhizobium fredii; Megaplasmid; Nitrogen fixation

\section{INTRODUCTION}

It is known that bacteria of the genus of Rhizobium the formed of nodule on the roots of certain of leguminous plants and fixing the molecular nitrogen in the symbiosis with the plant at the same time they produce several physiologically active substances, gave a positive effect on the leguminous plants. Nodule bacteria play an important role in enriching the soil with nitrogen. Bacteria of the genus rhizobium - is an aerobic gram-negative rods $0,7-1,8 \mathrm{~mm}$ long living in the soil and the plant surface.

When infected bean cause of recent education of nodule roots formations. Penetrated to the root of a hair, they cause the active root cell division that leads to the appearance of nodules. Its nodule bacteria grow and become thickened, branched forms - the so-called Bacteroides, most intense binding molecular nitrogen. Nodule bacteria metabolize as ammonium salts, nitrates, amino acids, and other compounds.

For their carbon source can be mono- and disaccharides, some polysaccharides, organic acids, alcohols. On dense media nodule bacteria form round colorless, transparent, slimy colonies, growing well at $25{ }^{\circ} \mathrm{C}$. Nodules formed active rhizobia contain pigment leghemoglobin and therefore painted in pink. Different nodule bacteria cause the development of nodules in certain leguminous plants: Rhizobium meliloti - alfalfa, clover; Rhizobium leguminosarum - peas and broad beans; Rhizobium trifolii is specific only for clover, Bradyrhizobium japonicum and Sinorhizobium fredii for soybeans. After the destruction of nodule, the nodule bacteria can live in the soil as saprophytes. The objective of these studies is the selection of nodule bacteria from soybean plants.

\section{MATERIALS AND METHODS}

In the Experiments, the plants of soybean (Glycine max). Large pink nodules were collected from the different layers of the root system of each plant during the phase of mass flowering plants, Tashkent region. For the isolation of pure cultures of soybean root nodule bacteria used method Israelskee [1] with some modifications as described in the methodological recommendations. Purification bacteria was performed with $4 \mathrm{x}$ reseeding typical colonies obtained exhausting stroke dilution method. For the growing culture of nodule bacteria used medium as described in the methodological manual [1].

Micro vegetation experiments carried out in glass tubes size $3 \times 25 \mathrm{~cm}$ filled $1 / 3$ of sterile vermiculite under greenhouse conditions in a special artificial climate room with an air temperature in the daytime $27-30{ }^{\circ} \mathrm{C}, 20-30{ }^{\circ} \mathrm{C}$ night, $50 \%$ relative humidity, light intensity of $200 \mathrm{~W} / \mathrm{m}^{2} 16$-hour photoperiod. Seeds of soybean plants for micro vegetation experiments was sterilized prior to seeding with sulfuric acid and up to 5 minutes, and then washed with sterile tap water to a $\mathrm{pH}$ of 7.0. Sterile seeds were placed in Petri dishes containing 1\% agar, to maintain humidity. Next was charged in a Thermostat at a temperature of $28^{\circ} \mathrm{C}$ for $2-3$ days. The shoots of the plants were placed in a glass tube $3 \times 25 \mathrm{~cm}$ in size, filled to $1 / 3$ with sterile vermiculite and grown for 35-40 days

\begin{tabular}{|c|c|}
\hline Quick Res! & 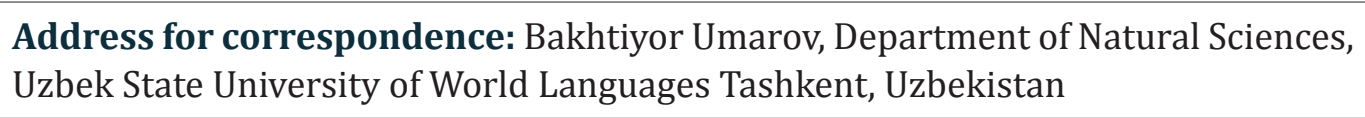 \\
\hline 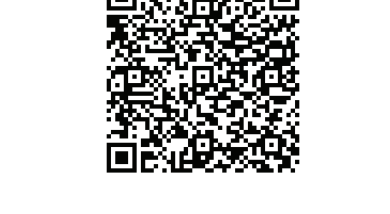 & $\begin{array}{l}\text { Received: April 07, } 2021 \text { Published: April 30, } 2021 \\
\text { How to cite this article: Bakhtiyor U. New Rhizobial Bacteria of the Genus Sinorhizobium } \\
\text { Fredii Entering Symbiosis with Soybean Plants. 2021- 3(2) OAJBS.ID.000273. DOI: } 10.38125 \text {, } \\
\text { OAJBS.000273 }\end{array}$ \\
\hline
\end{tabular}


in 6-fold replicates. Nitrogen-fixing ability of isolates Sinorhizobium fredii determined by acetylene [2] with a flame ionization detector gas chromatograph ЛХМ-80 (USSR) and expressed in nM. Morphophysiological properties of selected bacterial isolates were studied by standard methods [3]. Genetic analysis on the plasmid preparations were performed according to the method Eckhardt [4]. To determine the ability of bacteria to absorb different types of carbohydrates as sole carbon source was used sucrose, glucose (concentration of carbohydrates in the bean liquid medium was $1 \%)$. Microscopic analysis of cell nodule bacteria was conducted on a light microscope "Olympus" (Japan).

\section{RESULTS AND DISCUSSION}

The legume plants were growing in the soils of the experimental field, where before grew legumes were sown for several years. To isolate nodule bacteria of leguminous plants, the selected soybean plants were in the flowering - fruiting phase: well-developed plants and their roots were selected, dense, large, pink nodules were selected. Isolation of nodule bacteria was carried out as described in the materials and methods.

The isolates were plated on Petri dishes containing a special nutrient medium and kept in a thermostat at a temperature of 27$28^{\circ} \mathrm{C}$. After 3 days of incubation in growth medium plates separate single colonies appeared seeded bacteria. Within 7-10 days the growth of the bacteria was observed. During this time, the soybean nodule bacteria acquired colorless color touch and a smooth consistency (Figure 1).

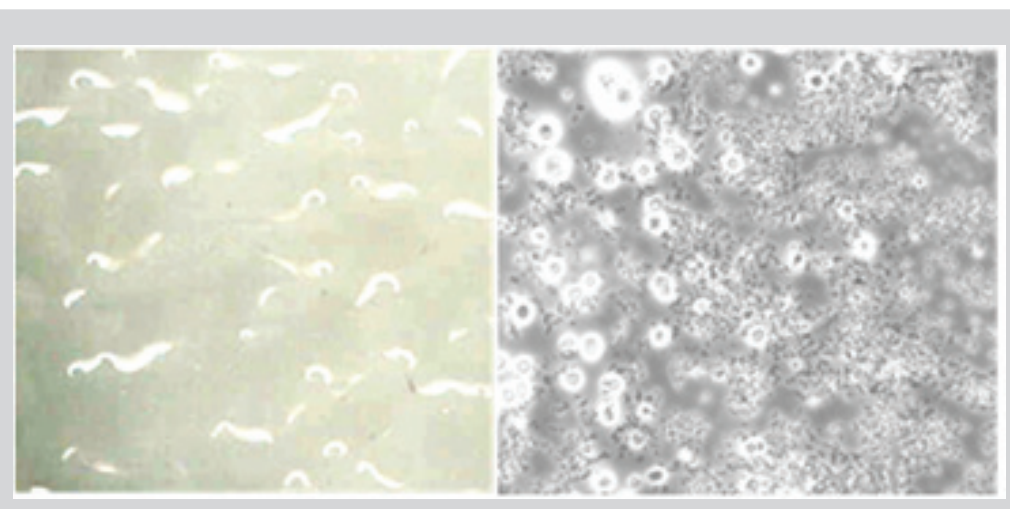

Figure 1: The rhizobia cells.

According to the morphological type of the isolated bacteria classified in the group of bacteria of the genus Rhizobium (rodshaped with rounded ends). Genetic structure consisted of one chromosome and several mega plasmids composed a very long

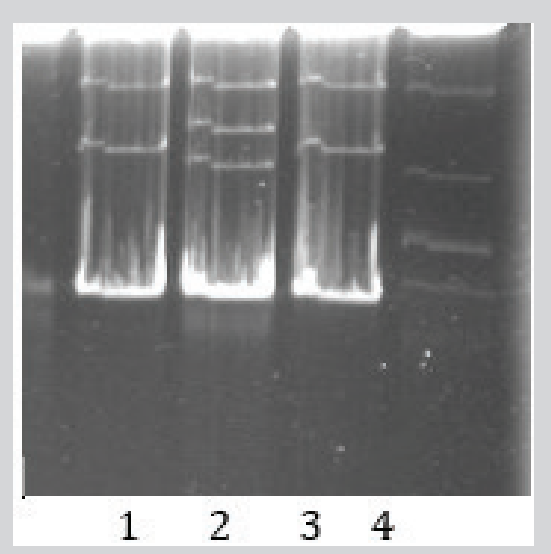

Figure 2: Plasmid profiles of S.fredii (1,2,3, S.ferdi -T1, S.ferdi -T2, S.ferdi -T3, 4. S.meliloti 41).

Figure 2 shows the results of detection of the plasmids these isolates $S$. ferdi -T1, S. ferdi -T2, S. ferdi -T3 compared to the type of strain $S$. meliloti 41 from the collection DSMC (Germany). To determine the species, isolates were plated on medium (MRS) with various components of carbon nutrition and plain agar (MPA). From the reference it is known that soybean root nodule bacteria species B. japonicum grow well on MRS medium with mannitol and glucose, do not grow on media containing disaccharides (sucrose, lactose, maltose) and meat peptone agar (MPA). Soybean nodule bacteria species $S$. fredii grow well on MRS media with all sources circular DNA molecule. By electrophoresis of cell lysates using the method of Eckhardt [4], we have found 3 mega plasmid with dimensions of $1500,1600,1700 \mathrm{~kb}$ with respect to only these types of bacteria (Figure 2).

of carbon nutrition and environment MPA. After separation of the isolated strains of rhizobia soybeans on a certain kind, determined the time of appearance and size of cell colonies. Are plated into individual cups of the most typical strains studied colonies $S$. fredii. Fast-growing strains of $S$. fredii formed colonies on day 2-4, and slow-growing strains of B. japonicum should form colonies on the $7^{\text {th }}$ day after sowing. Pure cultures of soybean rhizobia species $S$. fredii gave good growth on MRS media with mannitol and glucose. To characterize the growth of strains of rhizobia on various sources of carbon nutrition was determined by the color change of the medium from inoculation in comparison with the control tube. Symbiotic nitrogen-fixing properties and the ability of isolates tested in micro vegetation experiments. Micro vegetation experiments were carried out under greenhouse conditions in the laboratory in 2019-2020.

S. fredii strains of nodule bacteria were collected in the logarithmic growth phase $10^{6}-10^{7}$ cells $/ \mathrm{ml}$ and used to inoculate $1 \mathrm{ml}$ of culture to each tube. Assimilation of molecular nitrogen rhizobia acetylene method has been tested, as described in materials and methods. As a result of this work has been allocated 3 strains of soybean nodule bacteria $S$. fredii. At determination aspectual accessories nodule bacteria were founded on got result and on the grounds of their specificity to plant master. Our results had to additional proof to earlier published publication about quickly - and slow-growing bacteria. Wilson [5] has shown that bacteria's rhizobia are divided on 2-greater groups fast-growing and slow-growing, sharply differing on sort of the features. The 
similar results are received and beside other authors shown that rhizobia sort S. fredii pertain to group fast growing bacteria and enter in symbiosis with plants of soybean [6]. There is much scientific works. In literature, denoted isolation of nodule bacteria Bradyrhizobium japonicum from plants of soybean that, basically, plants to soybean enter in symbiosis with these bacteria [7].

Keyser [8] with colleague have shown that fast-growing types of nodule bacteria from sort $S$. fredii meet in soils of the Dalney Vostok, (Russia) entering in symbiosis with plants of soybean. Khalid showed that peanut rhizobia on stressful soils are fast growing plants and phylogenetically related Rhizobium sp [9].

\section{DISCUSSION}

From above stated result and from result conducted similar work and beside authors, is shown that plants to soybean on its host specificity can enter in symbiosis of nitrogen-fixing bacteria $B$. japonicum and S. fredii.

Thereby, from presented given is seen that us for the first time in ground Uzbekistan is chosen fast-growing type of nodule bacteria of the sort of $S$. fredii from the plant soybean, On the grounds of foregoing, possible draw a conclusion: fast-growing types of nodule bacteria to soybean can meet on territory Uzbekistan and in Central-Asia regions where cultivate the soybean plants.

\section{REFERENCES}

1. Novikova AT, Simarov BV, Arriam L (1979) The methodical recommendations on reception new strains nodule bacteria and estimation their efficiency. p. 33.

2. Hardy RWF, Burns RC, Holsten RD (1973) Applications of the acetyleneethylene assay for measurement of nitrogen fixation. Soil Biol Biochem 5(1): 47-81.

3. Egorova NS (1989) Industrial Microbiology. p. 688.

4. Eckhardt $\mathrm{T}$ (1978) A rapid method for the identification of plasmid deoxyribonucleic acid in bacteria. Plasmid 1(4): 584-588.

5. Wilson JK (1944) Over five hundred reasons for abandoning the crossinoculation groups of legumes Soil Sci 58(1): 61-69.

6. Michael HS, Gerald HE (1982) Rhizobium fredii sp nov a fast-growing species that effectively nodulates soybeans. International Journal of Systematic Bacteriology 34(1): 484-489.

7. Jordan DC (1982) Transfer of Brady rhizobium gen nov a genus of slowgrowing, root nodule bacteria from leguminous plants. Int J Syst Evol Bacteriol 32(1): 136-139.

8. Keyser HH, Bohlod B, Hu TS, Weber DF (1982) Fast growing rhizobia isolated from the nodules of soybean. Science 215(4540): 1631-1632.

9. Rabia K, Xiao XZ, Rifat H, Mukhtar A (2020) Molecular characteristics of Rhizobia isolated from arachis hypogaea grown under stress environment. Sustainability 12(15): 6259. 